\title{
Pawel Folfas
}

Szkoła Główna Handlowa w Warszawie

e-mail: pawel.folfas@sgh.waw.pl

\section{BEZPOŚREDNIE INWESTYCJE ZAGRANICZNE I WZROST GOSPODARCZY W PAŃSTWACH G-5 ORAZ BRICS - ANALIZA PRZYCZYNOWOŚCI W SENSIE GRANGERA}

\section{FOREIGN DIRECT INVESTMENTS AND ECONOMIC GROWTH IN G-5 AND BRICS COUNTRIES - GRANGER CAUSALITY ANALYSIS}

DOI: $10.15611 / \mathrm{e} 21.2015 .3 .02$

JEL Classification: F21

Streszczenie: Opracowanie dotyczy związku między strumieniami napływających BIZ a wzrostem realnego PKB w dziesięciu państwach: we Francji, Japonii, Niemczech, USA i Wielkiej Brytanii oraz w Brazylii, Chinach, Indiach, Rosji i RPA w latach 1971-2012. Analiza oparta jest na teście przyczynowości w sensie Grangera, a celem badania jest odpowiedź na pytanie, czy występuje jednokierunkowa czy dwukierunkowa (lub nie występuje wcale) przyczynowość między strumieniami napływających BIZ a wzrostem realnego PKB w dziesięciu gospodarkach należących do grup G-5 i BRICS. Na podstawie przeprowadzonych testów przyczynowości w sensie Grangera przynajmniej jednokierunkowa przyczynowość między strumieniami napływających BIZ a wzrostem realnego PKB jest potwierdzona tylko w dwóch z dziesięciu analizowanych państw (w Japonii i Indiach). W świetle wyników badania empirycznego oraz przeglądu literatury sformułowanie wniosków dotyczących wszystkich gospodarek lub chociażby wszystkich krajów wysoko rozwiniętych czy rozwijających się nie jest możliwe. Zasadne jest stwierdzenie, że związek przyczynowo-skutkowy między napływami BIZ a wzrostem realnego PKB jest kwestią indywidualną danej gospodarki i prawdopodobnie zależy od specyficznych czynników danej gospodarki goszczącej, a także od okresu analizy.

Słowa kluczowe: bezpośrednie inwestycje zagraniczne, wzrost gospodarczy, G-5, BRICS, przyczynowość w sensie Grangera.

Summary: Research concerns causality between FDI inflows and real GDP growth in ten countries: France, Germany, Japan, U.S., U.K., Brazil, China, India, Russia and South Africa during the period 1971-2012. The analysis is based on Granger-causality tests. The study is aimed at answering a question whether there is one way or two-way causality (or no causality at all) between FDI inflows and real GDP growth in G-5 and BRICS countries. According to the Granger-causality tests one-way causality occurs only in the case of Japan and India. Thus, Granger-causality between FDI inflows and real GDP growth seems to be a country-specific issue and any genral conlusions concerning developed or developing economies are not justified.

Keywords: Foreign Direct Investments, economic growth, G-5, BRICS, Granger causality. 


\section{Wstęp}

Związek przyczynowo-skutkowy między napływami bezpośrednich inwestycji zagranicznych (BIZ) a wzrostem gospodarczym jawi się jako istotne zagadnienie w ekonomii międzynarodowej. Liczne opracowania, zarówno teoretyczne, jak i empiryczne, poświęcone są napływom BIZ pobudzanych wzrostem gospodarczym (growth-driven FDI) oraz wzrostowi opartemu na napływach BIZ (FDI-led growth). Niniejsze opracowanie dotyczy związku między strumieniami napływających BIZ a wzrostem realnego PKB w dziesięciu państwach: we Francji, Japonii, Niemczech, USA i Wielkiej Brytanii (G-5) oraz w Brazylii, Chinach, Indiach, Rosji i RPA(BRICS)ํ. Analiza oparta jest na teście przyczynowości w sensie Grangera, a celem opracowania jest odpowiedź na pytanie, czy występuje jednokierunkowa czy dwukierunkowa (lub nie występuje wcale) przyczynowość między strumieniami napływających BIZ a wzrostem realnego PKB w dziesięciu gospodarkach należących do grup G-5 i BRICS. Choć z jednej strony wybór metody ogranicza możliwości badawcze (tylko ustalenie, czy szeregi czasowe - napływ BIZ i wzrost realnego PKB - niosą wzajemnie dla siebie wartość informacyjna), to $\mathrm{z}$ drugiej strony badanie jest przejrzyste i łatwo porównać jego wyniki z rezultatami wielu bardzo podobnych analiz. Ponadto, jak każda procedura ekonometryczna, tak i testowanie przyczynowości w sensie Grangera opiera się na wielu założeniach i obarczone jest pewnym marginesem błędu, czyli nie jest doskonałym testem uwzględniającym wszystkie aspekty związku przyczynowo-skutkowego.

Opracowanie poświęcone jest występowaniu oraz kierunkowi przyczynowości w sensie Grangera między strumieniami napływających BIZ (roczne napływy w bieżących cenach i kursach walutowych) oraz wzrostem realnego PKB (roczna zmiana PKB w cenach stałych z 2005 r.). Taki dobór danych statystycznych po raz kolejny wynika z chęci uczynienia badania prostym oraz porównywalnym $\mathrm{z}$ bardzo podobnymi studiami. Dopiero kolejnym krokiem może być badanie uwzględniające np. strumienie napływających BIZ w jednolitych kursach USD względem poszczególnych walut z 2005 r., co pozwoli na częściowe wyeliminowanie zakłóceń związanych z porównywaniem wielkości w cenach stałych (wzrost PKB) z wielkościami w cenach bieżących (napływy BIZ)². Próba obejmuje dziesięć państw - pięć rozwiniętych i pięć rozwijających się. W badaniu wykorzystano szeregi czasowe z bazy statystycznej UNCTAD dotyczące lat 1971-2012 (w przypadku Chin, Niemiec i Rosji szeregi czasowe są krótsze i zaczynają się odpowiednio w 1980, 1990 i 1993 roku).

${ }^{1}$ Taki dobór państw powoduje, iż analiza dotyczy najważniejszych gospodarek rozwiniętych i rozwijających się, pochodzących z różnych kontynentów.

${ }^{2}$ Warto jednak zauważyć, że badanie uwzględniające nominalne wartości strumieni napływających BIZ oraz zmiany realnego PKB ma istotny wymiar praktyczny. Wszak inwestorzy zagraniczni lokują kapitał w danej kwocie (kategoria nominalna), kierując się informacjami o zmianach realnego PKB. Ponadto urealnianie strumieni międzynarodowych przepływów towarów, usług czy kapitału jest o wiele bardziej kłopotliwe i mniej dokładne (kłopot z wyborem punktu odniesienia) niż deflowanie PKB. 
Opracowanie składa się z trzech zasadniczych części: przeglądu literatury (badania poświęcone przyczynowości w sensie Grangera między napływami BIZ a wzrostem gospodarczym), rozważań metodologicznych dotyczących testowania przyczynowości w sensie Grangera w przypadku niestacjonarnych szeregów czasowych oraz z wyników badania empirycznego dla państw G-5 i BRICS.

\section{Przegląd literatury}

Ten rozdział zawiera przegląd opracowań dotyczących przyczynowości w sensie Grangera między napływami BIZ (strumienie napływających BIZ w wartościach nominalnych) a wzrostem gospodarczym (wzrost realnego PKB) zarówno w krajach rozwiniętych, jak i rozwijających się. Wybór opracowań opiera się na dwóch kryteriach. Po pierwsze, pod uwagę zostały wzięte teksty koncentrujące się wyłącznie na analizie przyczynowości między napływami BIZ a wzrostem gospodarczym. Po drugie, zostały wybrane tylko analizy oparte na modelach VAR (modelach wektorowej autoregresji) lub modelach VEC (modelach korekty błędem) oraz na teście przyczynowości w sensie Grangera. W rezultacie możliwe jest porównanie wyników niniejszego badania (zob. rozdział 3) z wnioskami płynącymi z opracowań omówionych w tym rozdziale.

W przypadku krajów rozwiniętych badania empiryczne potwierdzają występowanie wzrostu gospodarczego opartego na BIZ na Cyprze, w Niemczech, Grecji, Irlandii, Japonii, na Malcie oraz w Szwecji. Ponadto napływy BIZ pobudzane wzrostem gospodarczym mają miejsce w Austrii, Danii, Finlandii, Norwegii, Portugalii oraz Szwecji. Warto zauważyć, że wnioski dotyczące trzech państw (Danii, Finlandii oraz Szwecji) różnią się między opracowaniami, co jest prawdopodobnie konsekwencją różnych okresów analizy. Szwecja jest jedynym państwem, w którym występuje dwukierunkowa przyczynowość między napływami BIZ a wzrostem gospodarczym (zob. tab. 1).

Podobnie jak w przypadku krajów rozwiniętych, tak i w krajach rozwijających się wyniki zależą od okresu analizy. Występowanie wzrostu gospodarczego opartego na BIZ jest potwierdzone testem przyczynowości w sensie Grangera w Angoli, Boliwii, Brazylii, Chile, Chinach, Ekwadorze, Filipinach, Ghanie, Gwatemali, Indiach, Indonezji, Kenii, Kolumbii, Malezji, Nepalu, Pakistanie, Salwadorze, Sri Lance, Tajlandii, Togo, Turcji i Wybrzeżu Kości Słoniowej. Ponadto napływy BIZ pobudzane wzrostem gospodarczym występują w Argentynie, Bangladeszu, Boliwii, Chile, Chinach, Kolumbii, RPA, Singapurze, Sri Lance i Tajlandii. Natomiast dwukierunkowa przyczynowość między napływami BIZ a wzrostem gospodarczym dotyczy tylko Boliwii, Chin, Ekwadoru, Indonezji, Kolumbii, Malezji, Pakistanu, Singapuru i Tajlandii (zob. tab. 1).

Podsumowując, jednokierunkowa lub dwukierunkowa przyczynowość (lub jej brak) między wzrostem realnego PKB a napływami BIZ jest kwestią indywidulną poszczególnych gospodarek goszczących. Nie ma możliwości ustalenia prawidło- 
Tabela 1. Przegląd opracowań poświęconych analizie przyczynowości w sensie Grangera między wzrostem PKB a napływami BIZ

\begin{tabular}{|c|c|c|c|c|c|c|c|}
\hline Autor/autorzy & $\begin{array}{l}\text { Gospodarki } \\
\text { goszczące }\end{array}$ & $\begin{array}{c}\text { Okres badania przyczynowości } \\
\text { w sensie Grangera }\end{array}$ & $\begin{array}{l}\text { Wyniki badania przyczynowości } \\
\text { w sensie Grangera }\end{array}$ & Autor/autorzy & $\begin{array}{c}\text { Gospodarki } \\
\text { goszczące }\end{array}$ & $\begin{array}{l}\text { Okres badania przyczynowości } \\
\text { w sensie Grangera }\end{array}$ & $\begin{array}{c}\text { Wyniki badania przyczynowości } \\
\text { w sensie Grangera }\end{array}$ \\
\hline 1 & 2 & 3 & 4 & 5 & 6 & 7 & 8 \\
\hline Afsar [2007] & Turcja & $\begin{array}{c}\text { pierwszy kwartał 1992- trzeci } \\
\text { kwartał } 2006\end{array}$ & $\begin{array}{c}\text { BIZ } \rightarrow \text { Wzrost PKB } \\
\text { Wzrost PKB } \mid \text { BIZ }\end{array}$ & Mah [2010] & Chiny & 1983-2001 & $\begin{array}{c}\text { BIZ | Wzrost PKB } \\
\text { Wzrost PKB } \rightarrow \text { BIZ }\end{array}$ \\
\hline $\begin{array}{l}\text { Asghar, } \\
\text { Nasreen } \\
\text { i Rehman } \\
{[2011]}\end{array}$ & $\begin{array}{c}\text { Bangladesz } \\
\text { Chiny } \\
\text { Filipiny } \\
\text { Indie } \\
\text { Indonezja } \\
\text { Korea Płd. } \\
\text { Japonia } \\
\text { Malediwy } \\
\text { Malezja } \\
\text { Nepal } \\
\text { Pakistan } \\
\text { Singapur } \\
\text { Sri Lanka } \\
\text { Tajlandia }\end{array}$ & 1983-2008 & $\begin{array}{c}\text { BIZ } \mid \text { Wzrost PKB } \\
\text { Wzrost PKB } \rightarrow \text { BIZ } \\
\text { BIZ } \mid \text { Wzrost PKB } \\
\text { Wzrost PKB } \mid \text { BIZ } \\
\text { BIZ | Wzrost PKB } \\
\text { Wzrost PKB } \mid \text { BIZ } \\
\text { BIZ | Wzrost PKB } \\
\text { Wzrost PKB } \mid \text { BIZ } \\
\text { BIZ | Wzrost PKB } \\
\text { Wzrost PKB } \mid \text { BIZ } \\
\text { BIZ | Wzrost PKB } \\
\text { Wzrost PKB } \mid \text { BIZ } \\
\text { BIZ } \rightarrow \text { Wzrost PKB } \\
\text { Wzrost PKB } \mid \text { BIZ } \\
\text { BIZ } \mid \text { Wzrost PKB } \\
\text { Wzrost PKB } \mid \text { BIZ } \\
\text { BIZ } \rightarrow \text { Wzrost PKB } \\
\text { Wzrost PKB } \rightarrow \text { BIZ } \\
\text { BIZ } \rightarrow \text { Wzrost PKB } \\
\text { Wzrost PKB } \mid \text { BIZ } \\
\text { BIZ } \mid \text { Wzrost PKB } \\
\text { Wzrost PKB } \rightarrow \text { BIZ } \\
\text { BIZ } \rightarrow \text { Wzrost PKB } \\
\text { Wzrost PKB } \mid \text { BIZ } \\
\text { BIZ } \mid \text { Wzrost PKB } \\
\text { Wzrost PKB } \rightarrow \text { BIZ } \\
\text { BIZ } \rightarrow \text { Wzrost PKB } \\
\text { Wzrost PKB } \mid \text { BIZ } \\
\end{array}$ & \begin{tabular}{|c|} 
Mawugnon \\
i Qiang [2011]
\end{tabular} & Togo & $1991-2010$ & $\begin{array}{l}\text { BIZ } \rightarrow \text { Wzrost PKB } \\
\text { Wzrost PKB| BIZ }\end{array}$ \\
\hline $\begin{array}{l}\text { Chowdhury } \\
\text { i Mavrotas } \\
{[2005]}\end{array}$ & $\begin{array}{c}\text { Chile } \\
\text { Malezja } \\
\text { Tajlandia }\end{array}$ & 1969-2000 & $\begin{array}{c}\text { BIZ } \mid \text { Wzrost PKB } \\
\text { Wzrost PKB } \rightarrow \text { BIZ } \\
\text { BIZ } \rightarrow \text { Wzrost PKB } \\
\text { Wzrost PKB } \rightarrow \text { BIZ } \\
\text { BIZ } \rightarrow \text { Wzrost PKB } \\
\text { Wzrost PKB } \rightarrow \text { BIZ }\end{array}$ & $\begin{array}{l}\text { Majagaiya } \\
{[2010]}\end{array}$ & Nepal & 1980-2006 & $\begin{array}{c}\text { BIZ } \rightarrow \text { Wzrost PKB } \\
\text { Wzrost PKB| BIZ }\end{array}$ \\
\hline
\end{tabular}


Tabela 1, cd.

\begin{tabular}{|c|c|c|c|c|c|c|c|}
\hline 1 & $\underline{\mathbf{2}}$ & 3 & 4 & 5 & 6 & 7 & 8 \\
\hline $\begin{array}{l}\text { Ericsson } \\
\text { i Irandoust } \\
{[2001]}\end{array}$ & $\begin{array}{c}\text { Dania } \\
\text { Finlandia } \\
\text { Norwegia } \\
\text { Szwecia }\end{array}$ & & $\begin{array}{c}\text { BIZ } \mid \text { Wzrost PKB } \\
\text { Wzrost PKB } \mid \text { BIZ } \\
\text { BIZ } \mid \text { Wzrost PKB } \\
\text { Wzrost PKB } \mid \text { BIZ } \\
\text { BIZ } \mid \text { Wzrost PKB } \\
\text { Wzrost PKB } \rightarrow \text { BIZ } \\
\text { BIZ } \rightarrow \text { Wzrost PKB } \\
\text { Wzrost PKB } \rightarrow \text { BIZ }\end{array}$ & $\begin{array}{c}\text { Moudatsou } \\
\text { i Kyrkillis } \\
\text { [2009] }\end{array}$ & $\begin{array}{c}\text { Austria } \\
\text { Cypr } \\
\text { Dania } \\
\text { Filipiny } \\
\text { Finlandia } \\
\text { Francja } \\
\text { Grecja } \\
\text { Holandia } \\
\text { Indonezia } \\
\text { Irlandia } \\
\text { Malta } \\
\text { Niemcy } \\
\text { Portugalia } \\
\text { Singapur } \\
\text { Szwecja } \\
\text { Tailandia } \\
\text { Włochy }\end{array}$ & $1970-2003$ & $\begin{array}{c}\text { BIZ } \mid \text { Wzrost PKB } \\
\text { Wzrost PKB } \rightarrow \text { BIZ } \\
\text { BIZ } \rightarrow \text { Wzrost PKB } \\
\text { Wzrost PKB } \mid \text { BIZ } \\
\text { BIZ } \mid \text { Wzrost PKB } \\
\text { Wzrost PKB } \rightarrow \text { BIZ } \\
\text { BIZ } \mid \text { Wzrost PKB } \\
\text { Wzrost PKB } \rightarrow \text { BIZ } \\
\text { BIZ } \mid \text { Wzrost PKB } \\
\text { Wzrost PKB } \rightarrow \text { BIZ } \\
\text { BIZ } \mid \text { Wzrost PKB } \\
\text { Wzrost PKB } \rightarrow \text { BIZ } \\
\text { BIZ } \rightarrow \text { Wzrost PKB } \\
\text { Wzrost PKB } \mid \text { BIZ } \\
\text { BIZ } \mid \text { Wzrost PKB } \\
\text { Wzrost PKB } \mid \text { BIZ } \\
\text { BIZ } \rightarrow \text { Wzrost PKB } \\
\text { Wzrost PKB } \rightarrow \text { BIZ } \\
\text { BIZ } \rightarrow \text { Wzrost PKB } \\
\text { Wzrost PKB } \mid \text { BIZ } \\
\text { BIZ } \rightarrow \text { Wzrost PKB } \\
\text { Wzrost PKB } \mid \text { BIZ } \\
\text { BIZ } \rightarrow \text { Wzrost PKB } \\
\text { Wzrost PKB } \mid \text { BIZ } \\
\text { BIZ } \mid \text { Wzrost PKB } \\
\text { Wzrost PKB } \rightarrow \text { BIZ } \\
\text { BIZ } \mid \text { Wzrost PKB } \\
\text { Wzrost PKB } \rightarrow \text { BIZ } \\
\text { BIZ } \mid \text { Wzrost PKB } \\
\text { Wzrost PKB } \rightarrow \text { BIZ } \\
\text { BIZ } \rightarrow \text { Wzrost PKB } \\
\text { Wzrost PKB } \rightarrow \text { BIZ } \\
\text { BIZ } \rightarrow \text { Wzrost PKB } \\
\text { Wzrost PKB } \mid \text { BIZ }\end{array}$ \\
\hline Esso [2010] & $\begin{array}{l}\text { Angola } \\
\text { Kamerun } \\
\text { Kongo }\end{array}$ & 1970-2007 & $\begin{array}{c}\text { BIZ } \rightarrow \text { Wzrost PKB } \\
\text { Wzrost PKB } \mid \text { BIZ } \\
\text { BIZ | Wzrost PKB } \\
\text { Wzrost PKB } \mid \text { BIZ } \\
\text { BIZ | Wzrost PKB } \\
\text { Wzrost PKB } \mid \text { BIZ }\end{array}$ & $\begin{array}{c}\text { Ocaya, Ruranga } \\
\text { i Kaberuka } \\
\text { [2013] }\end{array}$ & Rwanda & $1970-2010$ & $\begin{array}{c}\text { BIZ | Wzrost PKB } \\
\text { Wzrost PKB | BIZ }\end{array}$ \\
\hline
\end{tabular}




\begin{tabular}{|c|c|c|c|c|c|c|c|}
\hline & $\begin{array}{c}\text { Wybrzeże } \\
\text { Kości } \\
\text { Sloniowej } \\
\text { Ghana } \\
\text { Kenia } \\
\text { Liberia } \\
\text { Nigeria } \\
\text { Senegal } \\
\text { RPA }\end{array}$ & & $\begin{array}{c}\text { BIZ } \rightarrow \text { Wzrost PKB } \\
\text { Wzrost PKB } \mid \text { BIZ } \\
\\
\text { BIZ } \mid \text { Wzrost PKB } \\
\text { Wzrost PKB } \mid \text { BIZ } \\
\text { BIZ } \rightarrow \text { Wzrost PKB } \\
\text { Wzrost PKB } \mid \text { BIZ } \\
\text { BIZ } \mid \text { Wzrost PKB } \\
\text { Wzrost PKB } \rightarrow \text { BIZ } \\
\text { BIZ } \mid \text { Wzrost PKB } \\
\text { Wzrost PKB } \mid \text { BIZ } \\
\text { BIZ } \mid \text { Wzrost PKB } \\
\text { Wzrost PKB } \mid \text { BIZ } \\
\text { BIZ } \mid \text { Wzrost PKB } \\
\text { Wzzrost PKB } \rightarrow \text { BIZ }\end{array}$ & & & & \\
\hline $\begin{array}{l}\text { Feridun } \\
\text { i Sissoko } \\
{[2006]}\end{array}$ & Singapur & $1977-2002$ & $\begin{array}{c}\text { BIZ } \rightarrow \text { Wzrost PKB } \\
\text { Wzrost PKB| BIZ }\end{array}$ & $\begin{array}{l}\text { Pradhan } \\
{[2009]}\end{array}$ & $\begin{array}{l}\underline{\underline{\text { Filipinv }}} \\
\underline{\text { Indonezia }} \\
\text { Malezja } \\
\underline{\text { Singapur }} \\
\underline{\text { Tailandia }}\end{array}$ & 1970-2007 & $\begin{array}{c}\text { BIZ } \rightarrow \text { Wzrost PKB } \\
\text { Wzrost PKB } \rightarrow \text { BIZ } \\
\text { BIZ } \rightarrow \text { Wzrost PKB } \\
\text { Wzrost PKB } \rightarrow \text { BIZ } \\
\text { BIZ } \mid \text { Wzrost PKB } \\
\text { Wzrost PKB } \mid \text { BIZ } \\
\text { BIZ } \rightarrow \text { Wzzost PKB } \\
\text { Wzrost PKB } \rightarrow \text { BIZ } \\
\text { BIZ } \rightarrow \text { Wzrost PKB } \\
\text { Wzrost PKB } \rightarrow \text { BIZ }\end{array}$ \\
\hline $\begin{array}{l}\text { Guru-Gharana } \\
\text { i Adhikari } \\
\text { [2011] }\end{array}$ & $\underline{\text { Chiny }}$ & 1979-2008 & $\begin{array}{c}\text { BIZ } \rightarrow \text { Wzrost PKB } \\
\text { Wzrost PKB } \rightarrow \text { BIZ }\end{array}$ & Ray [2012] & Indie & 1990-2011 & $\begin{array}{c}\text { Wzrost PKB } \rightarrow \text { BIZ } \\
\text { BIZ | Wzrost PKB }\end{array}$ \\
\hline $\begin{array}{l}\text { Har, Teo } \\
\text { i Yee [2008] }\end{array}$ & Malezja & 1970-2005 & BIZ $\rightarrow$ Wzrost PKB & Samad [2009] & \begin{tabular}{c|} 
Argentyna \\
Bangladesz \\
Boliwia \\
Brazylia \\
Chile \\
$\underline{\text { Ekwador }}$ \\
Filipiny \\
Gwatemala
\end{tabular} & brak danych & $\begin{array}{c}\text { IZ } \rightarrow \text { Wzrost PKB } \\
\text { Wzrost PKB| BIZ } \\
\text { BIZ } \mid \text { Wzrost PKB } \\
\text { Wzrost PKB } \rightarrow \text { BIZ } \\
\text { BIZ } \rightarrow \text { Wzrost PKB } \\
\text { Wzrost PKB } \rightarrow \text { BIZ } \\
\text { BIZ } \rightarrow \text { Wzrost PKB } \\
\text { Wzrost PKB } \mid \text { BIZ } \\
\text { BIZ } \rightarrow \text { Wzrost PKB } \\
\text { Wzrost PKB } \mid \text { BIZ } \\
\text { BIZ } \rightarrow \text { Wzrost PKB } \\
\text { Wzrost PKB } \rightarrow \text { BIZ } \\
\text { BBIZ } \mid \text { Wzrost PKB } \\
\text { Wzrost PKB } \rightarrow \text { BIZ } \\
\text { BIZ } \rightarrow \text { Wzrost PKB } \\
\text { Wzrost PKB } \mid \text { BIZ }\end{array}$ \\
\hline
\end{tabular}


Tabela 1, cd.

\begin{tabular}{|c|c|c|c|c|c|c|c|}
\hline 1 & 2 & 3 & 4 & 5 & 6 & 7 & 8 \\
\hline & & & & & $\begin{array}{c}\text { Honduras } \\
\underline{\text { Indie }} \\
\underline{\text { Indonezja }} \\
\text { Kolumbia } \\
\text { Malezja } \\
\text { Meksyk } \\
\text { Pakistan } \\
\text { Salwador } \\
\text { Singapur } \\
\text { Sri Lanka } \\
\text { Tajlandia }\end{array}$ & & $\begin{array}{c}\text { BIZ } \mid \text { Wzrost PKB } \\
\text { Wzrost PKB } \mid \text { BIZ } \\
\text { BIZ } \rightarrow \text { Wzrost PKB } \\
\text { Wzrost PKB } \rightarrow \text { BIZ } \\
\text { BIZ } \rightarrow \text { Wzrost PKB } \\
\text { Wzrost PKB } \rightarrow \text { BIZ } \\
\text { BIZ } \rightarrow \text { Wzrost PKB } \\
\text { Wzrost PKB } \rightarrow \text { BIZ } \\
\text { BIZ } \mid \text { Wzrost PKB } \\
\text { Wzrost PKB } \mid \text { BIZ } \\
\text { BIZ } \mid \text { Wzrost PKB } \\
\text { Wzrost PKB } \mid \text { BIZ } \\
\text { BIZ } \rightarrow \text { Wzrost PKB } \\
\text { Wzrost PKB } \rightarrow \text { BIZ } \\
\text { BIZ } \rightarrow \text { Wzrost PKB } \\
\text { Wzrost PKB } \mid \text { BIZ } \\
\text { BIZ } \rightarrow \text { Wzrost PKB } \\
\text { Wzrost PKB } \rightarrow \text { BIZ } \\
\text { BIZ } \rightarrow \text { Wzrost PKB } \\
\text { Wzrost PKB } \mid \text { BIZ } \\
\text { BIZ } \rightarrow \text { Wzrost PKB } \\
\text { Wzrost PKB } \rightarrow \text { BIZ }\end{array}$ \\
\hline $\begin{array}{l}\text { Karikari } \\
{[1992]}\end{array}$ & Ghana & 1961-1988 & $\begin{array}{c}\text { BIZ } \mid \text { Wzrost PKB } \\
\text { Wzrost PKB } \rightarrow \text { BIZ }\end{array}$ & $\begin{array}{c}\text { Tang, } \\
\text { Selvanathan } \\
\text { i Selvanathan } \\
{[2008]} \\
\end{array}$ & Chiny & 1988-2003 & $\begin{array}{c}\text { BIZ } \rightarrow \text { Wzrost PKB } \\
\text { Wzrost PKB| BIZ }\end{array}$ \\
\hline Kim [2004] & $\begin{array}{l}\text { Filipiny } \\
\text { Indonezja } \\
\text { Malezja } \\
\text { Singapur } \\
\text { Tajlandia }\end{array}$ & $1970-2002$ & $\begin{array}{c}\text { BIZ | Wzrost PKB } \\
\text { Wzrost PKB| BIZ } \\
\text { BIZ | Wzrost PKB } \\
\text { Wzrost PKB } \rightarrow \text { BIZ } \\
\text { BIZ | Wzrost PKB } \\
\text { Wzrost PKB } \mid \text { BIZ } \\
\text { BIZ | Wzrost PKB } \\
\text { Wzrost PKB } \mid \text { BIZ } \\
\text { BIZ | Wzrost PKB } \\
\text { Wzrost PKB } \mid \text { BIZ } \\
\end{array}$ & $\begin{array}{c}\text { Yasemin } \\
\text { i Yalta [2011] }\end{array}$ & Chiny & $1982-2008$ & BIZ | Wzrost PKB \\
\hline $\begin{array}{l}\text { Magnus } \\
\text { i Fosu [2008] }\end{array}$ & Ghana & $\begin{array}{l}1970-1983 \\
1984-2002\end{array}$ & $\begin{array}{c}\text { BIZ } \mid \text { Wzrost PKB } \\
\text { Wzrost PKB| BIZ } \\
\text { BIZ } \rightarrow \text { Wzrost PKB } \\
\text { Wzrost PKB } \mid \text { BIZ }\end{array}$ & & & & \\
\hline
\end{tabular}

| brak przyczynowości w sensie Grangera; $\rightarrow$ przyczynowość w sensie Grangera

Źródło: opracowanie własne. 
wości, czy to dla gospodarek rozwiniętych lub rozwijających się, czy dla regionów świata. Nie pozwala na to różnorodność wyników analiz przyczynowości w sensie Grangera przedstawionych w tab. 1.

Taki stan rzeczy potwierdza również badanie przeprowadzone przez autora (zob. [Folfas 2013]), a poświęcone analizie przyczynowości w sensie Grangera między wzrostem realnego PKB a napływami BIZ w 36 krajach rozwiniętych w latach 1971-2011. Badanie to potwierdza występowanie dwukierunkowej przyczynowości w sensie Grangera między wzrostem PKB a napływami BIZ do Estonii, Hiszpanii, Łotwy i Słowenii. Ponadto wzrost realnego PKB jest przyczyną w sensie Grangera strumieni napływających BIZ do Belgii (wraz z Luksemburgiem), Bermudów, Cypru, Danii, Litwy, Niemiec i Polski. Dodatkowo napływy BIZ przyczyniają się w sensie Grangera do wzrostu realnego PKB Bułgarii, Finlandii, Malty i Węgier. A zatem nawet grupa gospodarek rozwiniętych jest dość zróżnicowana, jeżeli chodzi o przyczynowość w sensie Grangera między wzrostem realnego PKB a napływami BIZ.

\section{Analiza przyczynowości w sensie Grangera z wykorzystaniem procedury Toda-Yamamoto}

Jedną z najczęściej wykorzystywanych w ekonometrii koncepcji przyczynowości jest koncepcja autorstwa Grangera [1969]. Głównym jej założeniem jest fakt następstwa przyczynowo-skutkowego: jeżeli skutek występuje w okresie $t$, to przyczyna pojawia się w okresie $t-k^{3}$. Wiadomo jednocześnie, że przyczyna zawiera unikalne informacje o skutku, które są niedostępne w żaden inny sposób. Ogólna postać definicji przyczynowości Grangera jest sformułowana w następujący sposób: niech ogólnie $F(Y \mid X)$ oznacza warunkową dystrybuantę $Y$ przy danym $X$, niech $\Omega_{t}$ reprezentuje wszystkie informacje we wszechświecie w czasie $t$. Jeżeli dla każdego dodatniego $k$ zachodzi relacja: $F\left(Y_{t+k} \mid \Omega_{t}\right)=F\left(Y_{t+k}\left|\Omega_{t}\right| X\right)$, gdzie $\Omega_{t} \mid X_{t}$ oznacza wszystkie informacje we wszechświecie, oprócz zawartych w $X_{t}$ to $X_{t}$ nie jest przyczyną $Y_{t}$ W przeciwnym wypadku $X_{t}$ jest przyczyną $Y_{t}$ w sensie Grangera [Osińska 2008, s. 39-41].

Inaczej mówiąc, zmienna $X_{t}$ jest przyczyną w sensie Grangera zmiennej $Y_{t}$, jeżeli uwzględnienie w modelu objaśniającym $Y_{t}$ opóźnionych wartości zmiennej $X_{t}$ umożliwia uzyskanie lepszego opisu zmiennej $Y_{t}$. Z kolei w odniesieniu do możliwości prognozowania oznacza to tyle, że $X_{t}$ jest przyczyną $Y_{t}$ wtedy, gdy jesteśmy w stanie lepiej przewidywać przyszłe wartości $Y_{t}$, używając całego dostępnego zbioru informacji, niż używając zbioru informacji z wyłączeniem $X_{i}$.

3 Ewentualnie przyczyna może wystąpić w okresie $t$, wówczas mówimy o przyczynowości jednoczesnej lub natychmiastowej. 
Tabela 2. Procedura testowania przyczynowości w sensie Grangera

\begin{tabular}{|c|c|}
\hline \multicolumn{2}{|c|}{$\begin{array}{c}\text { Szeregi czasowe: } \\
\text { lnwzrostPKB } \text { i } \ln B I Z\end{array}$} \\
\hline \multicolumn{2}{|c|}{$\downarrow$} \\
\hline \multicolumn{2}{|c|}{$\begin{array}{c}\text { Badanie stacjonarności szeregów czasowych } \\
\text { za pomocą testów ADF i KPSS }\end{array}$} \\
\hline$\downarrow$ & $\downarrow$ \\
\hline Oba szeregi czasowe są stacjonarne & Oba szeregi czasowe są stacjonarne \\
\hline$\downarrow$ & $\downarrow$ \\
\hline$\downarrow$ & $\downarrow$ \\
\hline$\downarrow$ & $\downarrow$ \\
\hline $\begin{array}{c}\text { Ustalenie optymalnej liczby opóźnień }(k) \\
\text { w modelu VAR } \\
\text { za pomocą kryteriów informacyjnych } \\
\text { AIC, BIC oraz HQC }\end{array}$ & $\begin{array}{c}\text { Ustalenie optymalnej liczby opóźnień }(k) \\
\text { w modelu VAR } \\
\text { za pomocą kryteriów informacyjnych } \\
\text { AIC, BIC oraz HQC }\end{array}$ \\
\hline$\downarrow$ & $\downarrow$ \\
\hline $\begin{array}{c}\text { Oszacowanie modelu VAR }- \\
\text { liczba opóźnień wynosi } k \\
\ln B I Z_{t}=\gamma+\sum_{i=1}^{k} \alpha_{i} \ln B I Z_{t-i}+\sum_{i=1}^{k} \beta_{i} \operatorname{lnwzrost} P K B_{t-i}+\varepsilon_{t} \\
\text { lnwzrostPKB } B_{t}=\delta+\sum_{i=1}^{k} \sigma_{i} \operatorname{lnwzrostPKB_{t-i}+} \\
+\sum_{i=1}^{k} \mu_{i} \ln B I Z_{t-i}+\theta_{t}\end{array}$ & $\begin{array}{c}\text { Oszacowanie modelu VAR }- \\
\text { liczba opóźnień wynosi } k \\
\ln B I Z_{t}=\gamma+\sum_{i=1}^{k} \alpha_{i} \ln B I Z_{t-i}+\sum_{i=1}^{k} \beta_{i} \operatorname{lnwzrostPK} B_{t-i}+\varepsilon_{t} \\
\operatorname{lnwzrostPKB_{t}}=\delta+\sum_{i=1}^{k} \sigma_{i} \operatorname{lnwzrostPK} B_{t-i}+ \\
+\sum_{i=1}^{k} \mu_{i} \ln B I Z_{t-i}+\theta_{t}\end{array}$ \\
\hline$\downarrow$ & $\downarrow$ \\
\hline $\begin{array}{l}\text { Przeprowadzenie testów przyczynowości } \\
\text { w sensie Grangera w wariancie Walda }\end{array}$ & $\begin{array}{c}\text { Przeprowadzenie testów przyczynowości w } \\
\text { sensie Grangera w wariancie Walda }\end{array}$ \\
\hline
\end{tabular}

Źródło: opracowanie własne.

Testowanie przyczynowości w sensie Grangera uzależnione jest od tego, czy szeregi czasowe są stacjonarne. W przypadku niestacjonarnych szeregów czasowych testowanie jest bardziej skomplikowane i wymaga uwzględnienia dodatkowych zmiennych (większej liczby opóźnień zmiennych) zgodnie z procedurą Toda-Yamamoto [1995] - zob. tab. 2. W rezultacie pierwszym krokiem procedury testowania przyczynowości w sensie Grangera jest sprawdzenie stacjonarności zmiennych w tym opracowaniu zmiennymi są zlogarytmowane wartości wzrostu realnego PKB (lnwzrost $P K B$ ) oraz zlogarytmowane wartości strumieni napływających BIZ (lnBIZ). Następnie konstruowane są modele wektorowej autoregresji (VAR) - równania tych modeli zawiera tab. 2. Liczba opóźnień zmiennych lnwzrostPKB oraz lnBIZ uwzględnionych w modelach VAR zależy właśnie od poziomu zintegrowania szeregów czasowych oraz od optymalnej liczby opóźnień ustalonej na podstawie specjalnych testów zwanych kryteriami informacyjnymi. Ostatnim etapem procedury testowania przyczynowości w sensie Grangera jest przeprowadzenie testu Walda. 


\section{Wyniki analizy przyczynowości w sensie Grangera między wzrostem realnego PKB a napływami BIZ do państw G-5 oraz BRICS}

W badaniach przyczynowości w sensie Grangera zostały uwzględnione następujące zmienne (dane [UNCTAD, http://unctadstat.unctad.org]):

- wzrost realnego PKB (w cenach stałych z 2005 r.) Brazylii, Chin, Francji, Indii, Japonii, Niemiec, Rosji, RPA, USA oraz Wielkiej Brytanii (państwa G-5 oraz BRICS) w latach 1971-2012 (w przypadku Chin szereg czasowy rozpoczyna się w 1980 r., Niemiec w 1990 r., Rosji zaś w 1993 r.),

- wartości nominalne strumieni napływających BIZ do tych dziesięciu gospodarek w tym samym okresie.

Naturalnie zostały wykorzystane zlogarytmowane wartości wymienionych zmiennych oraz modele VAR zadane wzorami z tab. 2.

Tabela 3. Wyniki testów ADF na występowanie pierwiastka jednostkowego

Test ADF uwzględnia wyraz wolny

\begin{tabular}{|c|c|c|c|c|}
\hline Państwo & Zmienna & $\begin{array}{l}\text { Poziomy } \\
\text { zmiennej }\end{array}$ & $\begin{array}{l}\text { Pierwsze } \\
\text { różnice } \\
\text { zmiennej }\end{array}$ & $\begin{array}{c}\text { Stopień } \\
\text { zintegrowania szeregu } \\
\text { czasowego }\end{array}$ \\
\hline \multirow[t]{2}{*}{ Brazylia } & $\ln B I Z_{t}$ & $-0,263$ & $-5,843 * * *$ & $\mathrm{I}(1)$ \\
\hline & lnwzrostPKB ${ }_{t}$ & $-3,239 *$ & - & $\mathrm{I}(0)$ \\
\hline \multirow[t]{2}{*}{ Chiny } & $\ln B I Z_{t}$ & $-1,997$ & $-2,715^{*}$ & $\mathrm{I}(1)$ \\
\hline & lnwzrost $P K B_{t}$ & $-4,940 * * *$ & - & $\mathrm{I}(0)$ \\
\hline \multirow[t]{2}{*}{ Francja } & $\ln B I Z_{t}$ & $-1,513$ & $-3,591 * *$ & $\mathrm{I}(1)$ \\
\hline & lnwzrost $P K B_{t}$ & $-4,137 * * *$ & - & $\mathrm{I}(0)$ \\
\hline \multirow[t]{2}{*}{ Indie } & $\ln B I Z_{t}$ & $-0,663$ & $-6,215^{* * *}$ & $\mathrm{I}(1)$ \\
\hline & lnwzrostPKB ${ }_{t}$ & $-4,515^{* * *}$ & - & $\mathrm{I}(0)$ \\
\hline \multirow[t]{2}{*}{ Japonia } & $\ln B I Z_{t}$ & $-5,415 * * *$ & - & $\mathrm{I}(0)$ \\
\hline & lnwzrostPKB ${ }_{t}$ & $-3,596^{* *}$ & - & $\mathrm{I}(0)$ \\
\hline \multirow[t]{2}{*}{ Niemcy } & $\ln B I Z_{t}$ & $-3,413 *$ & - & $\mathrm{I}(0)$ \\
\hline & lnwzrostPKB ${ }_{t}$ & $-4,173 * * *$ & - & $\mathrm{I}(0)$ \\
\hline \multirow[t]{2}{*}{ Rosja } & $\ln B I Z_{t}$ & $-1,383$ & $-2,641 *$ & $\mathrm{I}(1)$ \\
\hline & $\operatorname{lnwzrost} P K B_{t}$ & $-6,851 * * *$ & - & $\mathrm{I}(0)$ \\
\hline \multirow[t]{2}{*}{ RPA } & $\ln B I Z_{t}$ & $-2,895^{*}$ & - & $\mathrm{I}(0)$ \\
\hline & lnwzrostPKB ${ }_{t}$ & $-3,502 *$ & - & $\mathrm{I}(0)$ \\
\hline \multirow[t]{2}{*}{ USA } & $\ln B I Z_{t}$ & $-2,054$ & $-4,341 * * *$ & $\mathrm{I}(1)$ \\
\hline & lnwzrostPKB ${ }_{t}$ & $-4,113 * * *$ & - & $\mathrm{I}(0)$ \\
\hline \multirow[t]{2}{*}{ Wielka Brytania } & $\ln B I Z_{t}$ & $-2,515$ & $-6,508 * * *$ & $\mathrm{I}(1)$ \\
\hline & $\operatorname{lnwzrost} P K B_{t}$ & $-4,233 * * *$ & - & $\mathrm{I}(0)$ \\
\hline
\end{tabular}


Tabela 3, cd.

Test ADF uwzględnia wyraz wolny i trend

\begin{tabular}{|c|c|c|c|c|}
\hline Państwo & Zmienna & $\begin{array}{l}\text { Poziomy } \\
\text { zmiennej }\end{array}$ & $\begin{array}{c}\text { Pierwsze } \\
\text { różnice zmiennej }\end{array}$ & $\begin{array}{c}\text { Stopień } \\
\text { zintegrowania szeregu } \\
\text { czasowego }\end{array}$ \\
\hline \multirow[t]{2}{*}{ Brazylia } & $\ln B I Z_{t}$ & $-2,228$ & $-5,816^{* * *}$ & $\mathrm{I}(1)$ \\
\hline & $\operatorname{lnwzrostPKB} B_{t}$ & $-3,170^{*}$ & - & $\mathrm{I}(0)$ \\
\hline \multirow[t]{2}{*}{ Chiny } & $\ln B I Z_{t}$ & $-1,427$ & $-3,049$ & $>\mathrm{I}(1)$ \\
\hline & $\operatorname{lnwzrostPKB_{t}}$ & $-4,743 * * *$ & - & $\mathrm{I}(0)$ \\
\hline \multirow[t]{2}{*}{ Francja } & $\ln B I Z_{t}$ & $-0,914$ & $-3,697^{*}$ & $\mathrm{I}(1)$ \\
\hline & $\operatorname{lnwzrostPKB_{t}}$ & $-4,910 * * *$ & - & $\mathrm{I}(0)$ \\
\hline \multirow[t]{2}{*}{ Indie } & $\ln B I Z_{t}$ & $-3,638^{*}$ & - & $\mathrm{I}(0)$ \\
\hline & $\operatorname{lnwzrost} P K B_{t}$ & $-5,463 * * *$ & - & $\mathrm{I}(0)$ \\
\hline \multirow[t]{2}{*}{ Japonia } & $\ln B I Z_{t}$ & $-5,352 * * *$ & - & $\mathrm{I}(0)$ \\
\hline & $\operatorname{lnwzrost} P K B_{t}$ & $-4,756 * * *$ & - & $\mathrm{I}(0)$ \\
\hline \multirow[t]{2}{*}{ Niemcy } & $\ln B I Z_{t}$ & $-3,316^{*}$ & - & $\mathrm{I}(0)$ \\
\hline & $\operatorname{lnwzrostPKB}{ }_{t}$ & $-4,326 * * *$ & - & $\mathrm{I}(0)$ \\
\hline \multirow[t]{2}{*}{ Rosja } & $\ln B I Z_{t}$ & $-1,735$ & $-2,303$ & $>\mathrm{I}(1)$ \\
\hline & $\operatorname{lnwzrostPKB} B_{t}$ & $-5,335 * * *$ & - & $\mathrm{I}(0)$ \\
\hline \multirow[t]{2}{*}{ RPA } & $\ln B I Z_{t}$ & $-3,825^{*}$ & - & $\mathrm{I}(0)$ \\
\hline & $\operatorname{lnwzrostPK} B_{t}$ & $-3,539 *$ & - & $\mathrm{I}(0)$ \\
\hline \multirow[t]{2}{*}{ USA } & $\ln B I Z_{t}$ & $-2,651$ & $-4,451 * * *$ & $\mathrm{I}(1)$ \\
\hline & lnwzrostPKB ${ }_{t}$ & $-4,179 * * *$ & - & $\mathrm{I}(0)$ \\
\hline \multirow[t]{2}{*}{ Wielka Brytania } & $\ln B I Z_{t}$ & $-3,884^{*}$ & - & $\mathrm{I}(0)$ \\
\hline & $\operatorname{lnwzrostPKB}{ }_{t}$ & $-4,247 * * *$ & - & $\mathrm{I}(0)$ \\
\hline
\end{tabular}

Poziomy istotności: *(10\%), **(5\%),***(1\%)

Źródło: opracowanie własne na podstawie testów przeprowadzonych w programie STATA.

Po pierwsze, została przeprowadzona analiza stacjonarności szeregów czasowych za pomocą testu ADF (zob. tab. 3) oraz testu KPSS (zob. tab. 4). W większości przypadków szeregi czasowe dotyczące napływów BIZ są niestacjonarne ${ }^{4}$ (z wyjątkiem Japonii, Niemiec i RPA), większość zaś szeregów czasowych dotyczących wzrostu realnego PKB jest stacjonarna ${ }^{5}$ (z wyjątkiem Brazylii i Rosji). W rezultacie konieczne jest uwzględnienie, zgodnie z procedurą Toda-Yamamoto, większej liczby opóźnień we wszystkich modelach VAR, z wyjątkiem modeli dla Japonii, Niemiec i RPA.

${ }^{4}$ Przyjmuje się, że szereg jest niestacjonarny, jeżeli chociaż jeden z trzech (dwa ADF plus jeden KPSS) testów wskazuje na niestacjonarność.

${ }^{5}$ Przyjmuje się, że szereg jest stacjonarny, jeżeli wszystkie trzy testy (dwa ADF plus jeden KPSS) wskazują na stacjonarność. 
Tabela 4. Wyniki testu KPSS na występowanie pierwiastka jednostkowego

Test KPSS uwzględnia wyraz wolny $\mathrm{i}$ trend

\begin{tabular}{|c|c|c|c|c|}
\hline Państwo & Zmienna & Poziomy zmiennej & $\begin{array}{l}\text { Pierwsze różnice } \\
\text { zmiennej }\end{array}$ & $\begin{array}{c}\text { Stopień } \\
\text { zintegrowania } \\
\text { szeregu czasowego }\end{array}$ \\
\hline \multirow[t]{2}{*}{ Brazylia } & $\ln B I Z_{t}$ & $0,23378 * * *$ & 0,0527951 & $\mathrm{I}(1)$ \\
\hline & $\operatorname{lnwzrost} P K B_{t}$ & $0,1671^{*}$ & 0,0347022 & $\mathrm{I}(1)$ \\
\hline \multirow[t]{2}{*}{ Chiny } & $\ln B I Z_{t}$ & $0,355729 * * *$ & 0,101501 & $\mathrm{I}(1)$ \\
\hline & lnwzrostPKB ${ }_{t}$ & 0,038939 & - & $\mathrm{I}(0)$ \\
\hline \multirow[t]{2}{*}{ Francja } & $\ln B I Z_{t}$ & $0,23738 * * *$ & 0,067341 & $\mathrm{I}(1)$ \\
\hline & $\operatorname{lnwzrost} P K B_{t}$ & 0,0584452 & - & $\mathrm{I}(0)$ \\
\hline \multirow[t]{2}{*}{ Indie } & $\ln B I Z_{t}$ & $0,207562 * *$ & 0,0591618 & $\mathrm{I}(1)$ \\
\hline & $\operatorname{lnwzrost} P K B_{t}$ & 0,0451451 & - & $\mathrm{I}(0)$ \\
\hline \multirow[t]{2}{*}{ Japonia } & $\ln B I Z_{t}$ & 0,0369127 & - & $\mathrm{I}(0)$ \\
\hline & $\operatorname{lnwzrost} P K B_{t}$ & 0,0580658 & - & $\mathrm{I}(0)$ \\
\hline \multirow[t]{2}{*}{ Niemcy } & $\ln B I Z_{t}$ & 0,056572 & - & $\mathrm{I}(0)$ \\
\hline & $\operatorname{lnwzrostPKB_{t}}$ & 0,0364592 & - & $\mathrm{I}(0)$ \\
\hline \multirow[t]{2}{*}{ Rosja } & $\ln B I Z_{t}$ & 0,0949653 & & $\mathrm{I}(0)$ \\
\hline & lnwzrostPKB ${ }_{t}$ & $0,177667 *$ & 0,0525574 & $\mathrm{I}(1)$ \\
\hline \multirow[t]{2}{*}{ RPA } & $\ln B I Z_{t}$ & 0,0612871 & - & $\mathrm{I}(0)$ \\
\hline & lnwzrostPKB ${ }_{t}$ & $0,135858 *$ & 0,0242689 & $\mathrm{I}(1)$ \\
\hline \multirow[t]{2}{*}{ USA } & $\ln B I Z_{t}$ & $0,280304 * * *$ & 0,0254509 & $\mathrm{I}(1)$ \\
\hline & $\operatorname{lnwzrost} P K B_{t}$ & 0,0908591 & - & $\mathrm{I}(0)$ \\
\hline \multirow[t]{2}{*}{ Wielka Brytania } & $\ln B I Z_{t}$ & 0,0621716 & - & $\mathrm{I}(0)$ \\
\hline & $\operatorname{lnwzrost} P K B_{t}$ & 0,12102 & - & $\mathrm{I}(0)$ \\
\hline
\end{tabular}

Poziomy istotności: *(10\%), **(5\%), ***(1\%)

Źródło: opracowanie własne na podstawie testów przeprowadzonych w programie GRETL.

Po drugie, na podstawie kryteriów informacyjnych została ustalona optymalna liczba opóźnień w modelach VAR (zob. tab. 5). Następnie została określona ostateczna liczba opóźnień z uwzględnieniem stopnia zintegrowania poszczególnych szeregów czasowych.

Po trzecie, przeprowadzono właściwy test przyczynowości w sensie Grangera (czyli test Walda), którego wyniki przedstawiono w tab. 6. Mimo względnie krótkich szeregów czasowych wykorzystanych w modelach VAR, testy statystyczne potwierdzają stabilność modelów VAR (z wyjątkiem modeli dla Japonii i Rosji), co przekłada się na wiarygodność testów przyczynowości w sensie Grangera. 
Tabela 5. Wybór liczby opóźnień zmiennych w modelu VAR

\begin{tabular}{|c|c|c|c|c|c|c|}
\hline Państwo & $\begin{array}{c}\text { Maksymalny } \\
\text { rząd } \\
\text { opóźnienia* }\end{array}$ & $\begin{array}{l}\text { Optymalna } \\
\text { liczba } \\
\text { opóźnień } \\
\text { wg kryterium } \\
\text { AIC }\end{array}$ & $\begin{array}{c}\text { Optymalna } \\
\text { liczba } \\
\text { opóźnień } \\
\text { wg kryterium } \\
\text { BIC }\end{array}$ & $\begin{array}{l}\text { Optymalna } \\
\text { liczba } \\
\text { opóźnień } \\
\text { wg kryterium } \\
\text { HQC }\end{array}$ & $\begin{array}{c}\text { Optymalna } \\
\text { liczba } \\
\text { opóźnień }(k)\end{array}$ & $\begin{array}{l}\text { Optymalna liczba } \\
\text { opóźnień po } \\
\text { uwzględnieniu } \\
\text { stopnia zintegrowania } \\
\text { szeregów }\left(k+d_{\max }\right)\end{array}$ \\
\hline Brazylia & 7 & 4 & 1 & 1 & 1 & 2 \\
\hline Chiny & 5 & 5 & 5 & 2 & 5 & 6 \\
\hline Francja & 7 & 1 & 1 & 1 & 1 & 2 \\
\hline Indie & 7 & 5 & 4 & 2 & 5 & 6 \\
\hline Japonia & 7 & 7 & 7 & 7 & 7 & 7 \\
\hline Niemcy & 4 & 1 & 1 & 1 & 1 & 1 \\
\hline Rosja & 4 & 1 & 1 & 1 & 1 & 2 \\
\hline RPA & 7 & 1 & 1 & 1 & 1 & 1 \\
\hline USA & 7 & 1 & 1 & 1 & 1 & 2 \\
\hline $\begin{array}{l}\text { Wielka } \\
\text { Brytania }\end{array}$ & 7 & 1 & 1 & 1 & 1 & 2 \\
\hline
\end{tabular}

* Około 15-20\% długości szeregu czasowego.

Źródło: opracowanie własne na podstawie testów przeprowadzonych w programie STATA.

Tabela 6. Test przyczynowości Grangera w wariancie Walda (uwzględniający procedurę Toda-Yamatoto dla szeregów niestacjonarnych)

\begin{tabular}{|c|c|c|}
\hline Państwo & $\begin{array}{c}\mathrm{H}_{0}: \ln B I Z \mid \operatorname{lnwzrost} P K B \\
\mathrm{H}_{1}: \ln F B I Z \rightarrow \operatorname{lnw} \text { wrost } P K B\end{array}$ & $\begin{array}{c}\mathrm{H}_{0}: \ln w z \operatorname{rost} P K B \mid \ln B I Z \\
\mathrm{H}_{1}: \ln w z \operatorname{rost} P K B \rightarrow \ln B I Z\end{array}$ \\
\hline Brazylia & 0,375 & 0,1385 \\
\hline Chiny & 0,00674 & 2,5631 \\
\hline Francja & 0,86452 & 2,3064 \\
\hline Indie & 0,09722 & $3,8379 *$ \\
\hline Japonia & $6,4475 * *$ & 0,19641 \\
\hline Niemcy & 0,14419 & 0,02185 \\
\hline Rosja & 1,3899 & 2,4557 \\
\hline RPA & 0,58018 & 0,06937 \\
\hline USA & 2,18 & 1,3055 \\
\hline Wielka Brytania & 0,24107 & 0,5598 \\
\hline
\end{tabular}

Poziomy istotności: *(10\%), **(5\%), ***(1\%)

| brak przyczynowości w sensie Grangera

$\rightarrow$ przyczynowość w sensie Grangera

Źródło: opracowanie własne na podstawie oszacowań przeprowadzonych w programie STATA.

Wyniki testu Walda nie potwierdzają występowania dwukierunkowej przyczynowości w sensie Grangera między wzrostem PKB a napływami BIZ w żadnej gospodarce. Ponadto wzrost realnego PKB jest przyczyną w sensie Grangera strumieni napływających BIZ do Indii. Dodatkowo napływy BIZ przyczyniają się 
w sensie Grangera do wzrostu realnego PKB Japonii. A zatem zarówno w grupie gospodarek rozwiniętych G-5, jak i w grupie państw BRICS w większości nie występuje przyczynowość w sensie Grangera między wzrostem realnego PKB a napływami BIZ.

\section{Zakończenie}

Generalnie bardziej intensywnym napływom BIZ towarzyszą wyższe stopy wzrostu realnego PKB. To współwystępowanie jest zazwyczaj silniejsze w przypadku gospodarek rozwiniętych. Jednakże ma ono słabe przełożenie na związki przyczynowo-skutkowe między napływami BIZ a wzrostami realnego PKB w państwach G-5 oraz BRICS. Na podstawie przeprowadzonych testów przyczynowości w sensie Grangera przynajmniej jednokierunkowa przyczynowość między strumieniami napływających BIZ a wzrostem realnego PKB jest potwierdzona w dwóch z dziesięciu analizowanych państw (w tym w jednym z pięciu państw G-5 oraz jednym z pięciu państw BRICS).

W świetle badania empirycznego oraz przeglądu literatury sformułowanie wniosków dotyczących wszystkich gospodarek, lub chociażby wszystkich krajów wysoko rozwiniętych czy rozwijających się, nie jest możliwe. Podobnie w odniesieniu do wniosków wyciągniętych przez Choe [2005], Chowdhury'ego i Mavrotasa [2005] oraz Handsena i Randa [2004] zasadne jest stwierdzenie, że związek przyczynowo-skutkowy między napływami BIZ a wzrostem gospodarczym jest kwestią indywidualną danej gospodarki i prawdopodobnie zależy od specyficznych czynników danej gospodarki goszczącej (a także od okresu analizy) ${ }^{6}$. A zatem należy być ostrożnym $\mathrm{w}$ formułowaniu wniosków dotyczących związków między napływami BIZ a wzrostem gospodarczym jedynie na podstawie analizy współwystępowania. Przygotowując prognozy gospodarcze, nie należy więc a priori zakładać, że istnieje związek przyczynowo-skutkowy między napływami BIZ a wzrostem gospodarczym. Jest to fundamentalny wniosek wynikający z omówionego (względnie prostego i mającego ograniczenia, o których wspominano we wstępie) badania. Kontynuacją tego badania mogą być analizy, po pierwsze, uwzględniające urealnioną wartość strumieni napływających BIZ, a po drugie, biorące pod uwagę strukturę rzeczową (projekty greenfield, fuzje i przejęcia, pożyczki wewnątrzkorporacyjne, reinwestycje zysków i strat) BIZ. Niestety obie propozycje dalszych badań związane są z technicznymi trudnościami dotyczącymi wyboru i/lub braku odpowiednich danych statystycznych.

${ }^{6}$ Prawdopodobnie jedną z przyczyn takiego stanu rzeczy jest to, że do BIZ wliczane są pożyczki wewnątrz korporacji transnarodowych oraz reinwestycje zysków i strat, które nie mają wiele wspólnego z koniunkturą gospodarczą, a najczęściej służą unikaniu opodatkowania. Nie bez znaczenia są też inwestycje typu greenfield czy transakcje fuzji i przejęcia związane z tworzeniem tzw. przedsiębiorstw fasadowych w celach podatkowych (szerzej SPV, czyli spółek - wehikułów specjalnego przeznaczenia). 


\section{Literatura}

Afsar M., 2007, The causality relationship between economic growth and foreign direct investment in Turkey, mimeo, conference on Business and Economics Society International.

Asghar N., Nasreen S., Rehman H., 2011, Relationship between FDI and economic growth in selected Asian countries: A panel data analysis, Review of Economics \& Finance, Academic Research Centre of Canada.

Choe J.I., 2003, Do foreign investment and gross domestic promote economic growth?, Review of Development Economics, no. 7, s. 44-57.

Chowdhury A., Mavrotas G., 2005, FDI and growth: A causal relationship, UNU-WIDER Research Paper, no. 2005/25.

Ericsson J., Irandoust M., 2001, On the causality between foreign direct investment and output: A comparative study, The International Trade Journal, vol. 15, no. 1, s. 122-132.

Esso L.J., 2010, Long-run relationship and causality between foreign direct investment and growth: Evidence from ten African countries, International Journal of Economics and Finance, vol. 2, no. 2, s. $168-177$.

Feridun M., Sissoko Y., 2006, Impact of FDI on economic development: A causality analysis for Singapore, mimeo, 6th Global Conference on Business \& Economics, Gutman Conference Center, USA.

Folfas P., 2013, Bivariate causality between FDI inflows and real GDP growth in developed economies, mimeo, ETSG 2013 conference.

Granger C.W.J., 1969, Investigating causal relations by econometric models and cross-spectral methods, Econometrica, vol. 3, no. 37, s. 424-438.

Guru-Gharana K., Adhikari D.R., 2011 , Econometric investigation of relationships among export, FDI and growth in China: An application of Toda-Yamamoto-Dolado-Lutkephol Granger Causality Test, Journal of International Business Research, vol. 10, no. 2, s. 31-50.

Hansen H., Rand J., 2004, On the casual links between FDI and economic growth in developing economies, mimeo, DERG, University of Copenhagen.

Har W.M., Teo K.L., Yee K.M., 2008, FDI and economic growth relationship: An empirical study on Malaysia, International Business Research, vol. 1, no. 2, s. 11-18.

Karikari J.A., 1992, Causality between foreign direct investment and economic output in Ghana, Journal of Economic Development, no. 17, s. 1-12.

Kim M., 2004, Does a Casual Link Exist between FDI and Economic Growth in the Asian NIEs?, mimeo, M.A. thesis at Ohio University.

Magnus F.J., Fosu O.-A.E., 2008, Bivariate causality analysis between FDI inflows and economic growth in Ghana, International Journal of Finance and Economics, no. 15, s. 103-112.

Mah J., 2010, Foreign direct investment inflows and economic growth of China, Journal of Policy Modeling, no. 32, s. 155-158.

Majagaiya K.P., 2010, A time series analysis of foreign direct investment and economic growth: A case study of Nepal, International Journal of Bussiness and Management, vol. 5, no. 2, s. 144-148.

Mawugnon A.K., Qiang F., 2011, The relationship between foreign direct investment and economic growth in Togo, Proceedings of the 8th International Conference on Innovation \& Management, s. $1269-1273$.

Moudatsou A., Kyrkillis D., 2009, FDI and economic growth: Granger Causality Tests in Panel Data Model-Comparative results in the case of European Union countries EU (European Union countries) and ASEAN Association of South East Asian Nations, mimeo, EEFS Conference in Warsaw.

Ocaya B., Ruranga Ch., Kaberuka W., 2013, Foreign direct investment and economic growth in Rwanda: A time series analysis, Journal of Business Management and Corporate Affairs, vol. 2, no. 1, s. 11-18. 
Osińska J., 2008, Ekonometryczna analiza zależności przyczynowych, Wydawnictwo UMK, Torun. Pradhan R.P., 2009, The FDI-led-growth hypothesis in ASEAN-5 countries: Evidence from cointegrated panel analysis, International Journal Business and Management, vol. 4, no. 12, s. 153-164.

Ray S., 2012, Impact of Foreign Direct Investment on Economic Growth in India: A Co-integration Analysis, Advances in Information Technology and Management, vol. 2, no. 1, s. 187-201.

Samad A., 2009, Does FDI Cause Economic Growth? Evidence from South-East Asia and Latin America, Working Paper of Woodbury School of Business, no. 1-09.

Tang S., Selvanathan E.A., Selvanathan S., 2008, Foreign direct investment, domestic investment, and economic growth in China. A time series analysis, UNU-WIDER Research Paper, no. 2008/19.

Toda H.Y., Yamamoto T., 1995, Statistical inference in vector autoregressions with possibly integrated processes, Journal of Econometrics, no. 66, s. 225-250.

UNCTAD, http://unctadstat.unctad.org (15.06. 2014).

Yasemin Yalta A., 2011, New evidence on the FDI-Led Growth: The case of China, Working Paper of TOBB University of Economics and Technology Department of Economics, no. 11-07. 